\title{
Estrogen-like activity of seafood related to environmental chemical contaminants
}

\author{
Sonia Garritano ${ }^{1}$, Barbara Pinto ${ }^{2}$, Marco Calderisi² ${ }^{2}$ Teresa Cirillo ${ }^{3}$, \\ Renata Amodio-Cocchieri ${ }^{3}$ and Daniela Reali*2
}

Address: ${ }^{1}$ IARC, 150 Cours Albert-Thomas, 69372 Lyon Cedex 08, France, ${ }^{2}$ Department of Experimental Pathology, Medical Biotechnology, Infectivology and Epidemiology, University of Pisa, Via San Zeno 37, 56127 Pisa, Italy and ${ }^{3}$ Department of Food Science, University of Naples Federico II, Via Università 100, 80055 Portici, Italy

Email: Sonia Garritano - garritanos@iarc.fr; Barbara Pinto - b.pinto@med.unipi.it; Marco Calderisi - calderisi@chemiometria.it; Teresa Cirillo - tcirillo@unina.it; Renata Amodio-Cocchieri - amodio@unina.it; Daniela Reali* - d.reali@med.unipi.it

* Corresponding author

\section{Published: 30 March 2006}

Environmental Health: A Global Access Science Source 2006, 5:9 doi:10.1 186/1476-069X-59

This article is available from: http://www.ehjournal.net/content/5/l/9

(C) 2006 Garritano et al; licensee BioMed Central Ltd.

This is an Open Access article distributed under the terms of the Creative Commons Attribution License (http://creativecommons.org/licenses/by/2.0), which permits unrestricted use, distribution, and reproduction in any medium, provided the original work is properly cited.
Received: 28 September 2005

Accepted: 30 March 2006

\begin{abstract}
Background: A wide variety of environmental pollutants occur in surface waters, including estuarine and marine waters. Many of these contaminants are recognised as endocrine disrupting chemicals (EDCs) which can adversely affect the male and female reproductive system by binding the estrogen receptor and exhibiting hormone-like activities. In this study the estrogenic activity of extracts of edible marine organisms for human consumption from the Mediterranean Sea was assayed.
\end{abstract}

Methods: Marine organisms were collected in two different areas of the Mediterranean Sea. The estrogenic activity of tissues was assessed using an in vitro yeast reporter gene assay (S. cerevisiae RMY 326 ER-ERE). Concentrations of polychlorinated biphenyls (PCBs) (congeners 28, 52, I0I, $118,138,153,180)$ in fish tissue was also evaluated.

Results: Thirty-eight percent of extracts showed a hormone-like activity higher than $10 \%$ of the activity elicited by $10 \mathrm{nM} 17 \mathrm{~b}$-estradiol (E2) used as control.

Total PCB concentrations ranged from 0.002 up to $1.785 \mathrm{ng} / \mathrm{g}$ wet weight. Chemical analyses detected different levels of contamination among the species collected in the two areas, with the ones collected in the Adriatic Sea showing concentrations significantly higher than those collected in the Tyrrhenian Sea $(p<0.01)$.

Conclusion: The more frequent combination of chemicals in the samples that showed higher estrogenic activity was PCB 28, PCB I0I, PCB I53, РCB 180.

The content of $\mathrm{PCBs}$ and estrogenic activity did not reveal any significant correlation.

\section{Background}

A wide variety of environmental pollutants occur in surface waters, including estuarine and marine waters. Many of these contaminants are recognised as endocrine disrupting chemicals (EDCs) and include substances of very different chemical property such as therapeutic agents, 
alkylphenols, dioxins, pesticides, plasticizers and surfactants. Of particular concern are the polychlorinated biphenyls (PCBs) because of their ubiquity and their lipophilic and persistent nature (they tend to accumulate within the fat and tissue of animals and humans). These compounds are widely spread in the environment despite most countries have banned their production. They continue to be detected in the ecosystem including marine habitat because of deliberate or accidental dumping or through disposal of goods containing them. There is evidence that these chemicals can adversely affect the male and female reproductive system by binding the estrogen receptor and exhibiting estrogenic or anti-estrogenic activities [1-3]. The susceptibility of target tissues is related to the stage of development, the immune status of the individual and the cumulative exposure dose. Twelve PCBs congeners, PCBs 77, 81, 126 and 169 (non-ortho PCBs), PCBs 105, 114, 118, 123, 156, 157, 167 and 189 (ortho PCBs), were identified by the WHO as having dioxin-like properties, and 7 congeners (PCBs 28, 52, 101, 118, 153, 138,180 ) were identified by the International Council for the Exploration of the Seas (ICES) as markers of the degree of contamination. These compounds are the second greatest cause of fish advisory, according to US-EPA [4]. The main source of exposure to PCBs for humans is represented by food, specifically of animal origin [5-7]. In epidemiological studies, PCBs have been associated with immunotoxicity [8] and neurobehavioral deficits have been reported in children prenatally exposed to PCBs and through mother's milk [9] or ascribed to the consumption of PCB contaminated food including fish accumulating these substances directly from the surrounding environment [10-12].

In this study the estrogenic activity of extracts of edible marine organisms from two areas of the Mediterranean Sea was assayed in order to evaluate the exposure of edible species of the Mediterranean Sea largely consumed in the Italian diet to complex mixtures of xenobiotics that may exhibit estrogenic activities. We also evaluated the concentration of ICES-7 PCBs considered as target compounds in marine pollution studies.

\section{Methods \\ Sampling}

Fish, crustaceans and cephalopods were collected directly from professional fishing in two areas of the Mediterranean Sea, the Adriatic Sea within 40 miles S-E from the Pescara port, and Tyrrhenian Sea within 50 miles S-W from the Naples port, respectively, from June to July 2004. The organisms collected in the Adriatic Sea were Bluemouth (Helicolenus dactylopterus), Broad-tail shortfin squid (Illex coindetii), Red mullet (Mullus barbatus), European hake (Merluccius merluccius), Fork beard (Phycis phycis), Deepwater rose shrimp (Parapenaeus longirostris),
Atlantic mackerel (Scomber scombrus); in Tyrrhenian Sea were Common squid (Loligo vulgaris), Red mullet (Mullus barbatus), Common grey mullet (Mugil cephalus), Fork beard (Phycis phycis), Blue whiting (Micromesistius poutassou), Common octopus (Octopus vulgaris), Gilt-head seabream (Sparus aurata), Common cuttlefish (Sepia officinalis), Atlantic mackerel (Scomber scombrus). These organisms, that represent different trophic positions in the marine environment, were selected because they are abundant, widely distributed in the Mediterranean area and available all over the year and also because they represent a largely consumed seafood. The specimens, all of commercial size, were wrapped in aluminium foil, then immediately refrigerated and transported to the laboratory.

\section{Analytical sample preparation}

Each species was classified; the length and weight of each specimen were measured and recorded. The specimens with weight $>200 \mathrm{~g}$ were individually analysed, those with weights $<200 \mathrm{~g}$ were pooled, obtaining 20 analytical samples from the Adriatic Sea and 22 from the Tyrrhenian Sea. The edible part of the marine organisms was selected, homogenised, and subsequently lyophilised.

\section{Fat extraction}

Fat was cold-extracted from lyophilised tissues with petroleum ether/acetone $(1: 1, \mathrm{v} / \mathrm{v})$. The extract was passed through a glass tube packed with anhydrous sodium sulphate and then evaporated by rotavapor $\left(40^{\circ} \mathrm{C}\right.$ and low pressure) and the lipid residue was weighed.

\section{Chemical analysis}

The cleanup of fat extracts $(50 \mathrm{mg}$ ) was carried out on Extrelut-NT3/Extrelut-NT1 cartridges (Merck KGaA Darmstadt, Germany) with the addition of $0.36 \mathrm{~g}$ of C-18 Isolute (40-60 mesh Merck KGaA Darmstad, Germany) and eluted with acetonitrile. The extracts were concentrated under vacuum at $40^{\circ} \mathrm{C}$, cleaned up by column adsorption-chromatography on Florisil (60/100 mesh Supelco Bellefonte, PA USA) activated at $130^{\circ} \mathrm{C}$ for $2 \mathrm{~h}$ and eluted with $30 \mathrm{ml} \mathrm{n}$-hexane added in $5 \mathrm{ml}$ aliquots. The eluate was concentrated to a small volume $(<1 \mathrm{ml})$ by evaporation at room temperature under a flow of $\mathrm{N}_{2}$, and $1 \mathrm{ml}$ isooctane was added as a keeper. Seven PCB congeners (IUPAC nn. 28, 52, 101, 118, 153, 138 and 180) were detected in seafood according to the analytical method of Italian Public Health laboratories [13].

For PCBs quantification, samples were injected into a capillary gas chromatographer with electron capture detector (GC-ECD) with Temperature program $60^{\circ} \mathrm{C}$ for 2 minutes, increasing of $10^{\circ} \mathrm{C} / \mathrm{min}$ to $170^{\circ} \mathrm{C}$ stay for 2 minutes, increasing of $2^{\circ} \mathrm{C} / \mathrm{min}$ to $210^{\circ} \mathrm{C}$, increasing for $10^{\circ} \mathrm{C} / \mathrm{min}$ to $260^{\circ} \mathrm{C}$. GC-MS was used for their confirm. The internal 


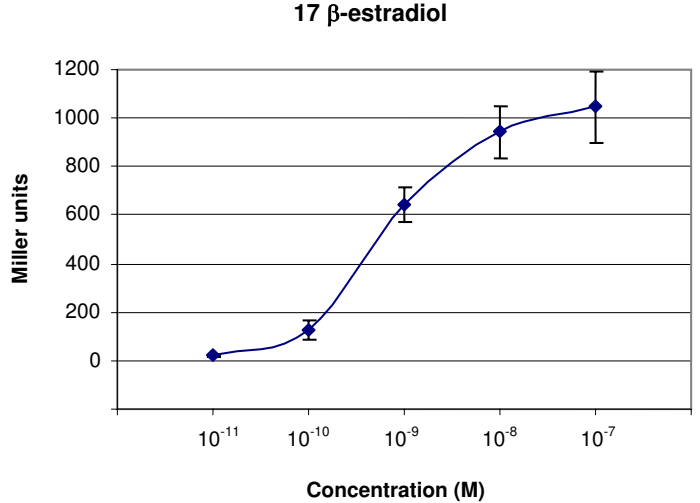

Figure I

Dose-response curve of E2 concentrations. Data represent the mean \pm S.D. of sixteen independent experiments.

standard solution (PCB 209) was added to the extract before injecting. The evaluation of $\mathrm{PCB}$ concentrations in the samples was carried out by comparison with a calibration curve obtained by a pool of the seven ICES PCB congeners: PCB 28 (2, 4, 4' tri-chlorobiphenyls), PCB 52 (2, 2', 5, 5' tetra-chlorobiphenyls), РCB $101(2,4,5,2 '$ ' 5' penta-chlorobiphenyls), PCB $118\left(2,4,5,33^{\prime}, 4\right.$ ' pentachlorobiphenyls), PCB $138\left(2,2^{\prime} 3,4,44^{\prime}, 5^{\prime}\right.$ hexa-chlorobiphenyls) PCB $153\left(2,2^{\prime}, 4.4^{\prime}, 5,5^{\prime}\right.$ hexa-chlorobiphenyls) and PCB 180 (2, 2', 3, 4, 4', 5, 5' hepta-chlorobiphenyls). All of the compounds (95\% - 99\% pure) were purchased from Dr. Ehrenstorfer (GmbH, Augsburg, Germany). In the analytical conditions applied, the detection limits were: $0.002 \mathrm{ng} / \mathrm{g}$ wet weight ( $\mathrm{w} \mathrm{wt}$ ) for the PCBs nn 180 and 138; $0.003 \mathrm{ng} / \mathrm{g}$ (w wt) for the PCB n 153; $0.005 \mathrm{ng} /$ $\mathrm{g}(\mathrm{w} w \mathrm{wt})$ for the PCBs nn 52, 101, 118 and $0.008 \mathrm{ng} / \mathrm{g}$ ( $\mathrm{w}$ $\mathrm{wt}$ ) for the PCB $\mathrm{n} 28$. The mean recovery obtained by PCB standard spiked samples was $70 \pm 7 \%$. Total PCB levels were calculated as the sum $(\Sigma)$ of all the seven determined congeners.

\section{Yeast strain}

Estrogenic activity of organic extracts of seafood (200 g wet weight) and standard PCBs was tested by $S$. cerevisiae yeast strain (RMY326 ER-ERE) containing the human estrogen receptor (hERa) and a Xenopus laevis vitellogenin estrogen-responsive element (ERE) linked to a reporter gene lac $Z$ encoding for the enzyme $\beta$-galactosidase. Plasmid $p G / \operatorname{ER}(G)$ was used as the yeast expression vector for $\mathrm{ER} \alpha$ and PUCASS-ERE as its b-galactosidase reporter plasmid $[14,15]$. The sensitivity and specificity of the yeast strain were previously assessed using 17b-estradiol (E2), diethylstilbestrol (DES), and other natural and synthetic chemicals $[16,17]$.

\section{Medium}

A synthetic drop-out selective medium lacking uracil and thryptophane to maintain plasmid selection was prepared by adding 0.67 g yeast nitrogen base, $2 \%$ glucose, $10 \mathrm{ml} \mathrm{a}$ stock aminoacids solution (30 mg L-isoleucine, $150 \mathrm{mg} \mathrm{L}$ valine, $20 \mathrm{mg} \mathrm{L}$ - arginine- $\mathrm{HCl}, 30 \mathrm{mg}$ L-lysine- $\mathrm{HCl}, 20 \mathrm{mg}$ L-methionine, $50 \mathrm{mg}$ L-phenylalanine, $200 \mathrm{mg}$ L-threonine, $30 \mathrm{mg}$ L-tyrosine in $100 \mathrm{ml}$ water), $1 \mathrm{ml}$ a stock Lhystidine- $\mathrm{HCl}$ solution (200 mg in $100 \mathrm{ml}$ water), $1 \mathrm{ml} \mathrm{a}$ stock L- leucine solution ( $1 \mathrm{gr}$ in $100 \mathrm{ml}$ water) and an adenine hemisulfate solution (200 mg in $100 \mathrm{ml}$ water) to $90 \mathrm{ml}$ water endotoxin-free cell cultures (Sigma). BactoAgar (DIFCO) (3 g) was used for the solid media.

\section{Yeast assay}

Yeast cultures were incubated at $28^{\circ} \mathrm{C}$ for $7 \mathrm{hr}$ by continuously shaking on an orbital shaker $(210 \mathrm{rpm})$ in $1 \mathrm{ml}$ of selective medium. The cultures were then diluted in fresh medium to an optical density of $0.1\left(\mathrm{OD}_{600} \mathrm{~nm}\right)$ and incubated at $30^{\circ} \mathrm{C}$ for $17 \mathrm{~h}$ (overnight) in the absence or

\section{Log(Total PCBs)}

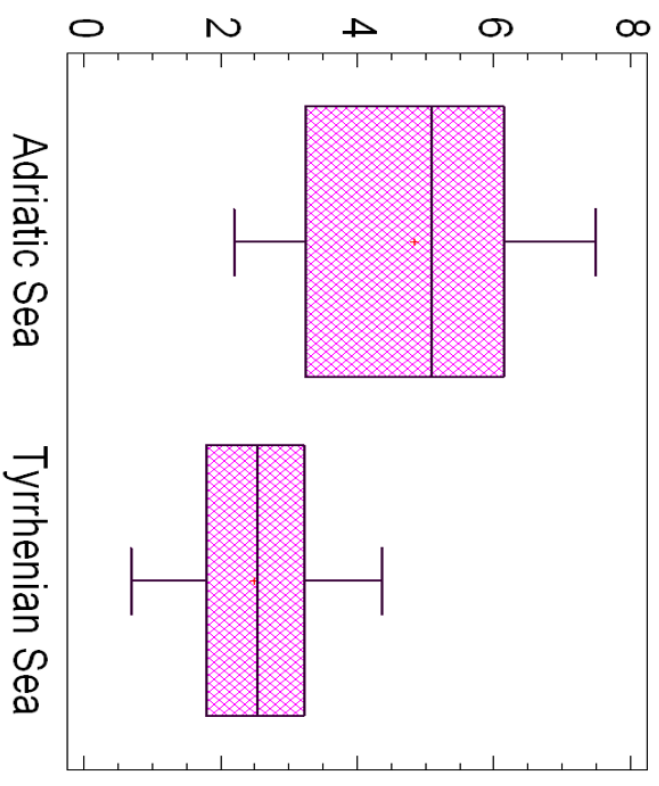

Figure 2

Differences in total PCBs content (Log) in samples from the Adriatic and the Tyrrhenian Sea. 


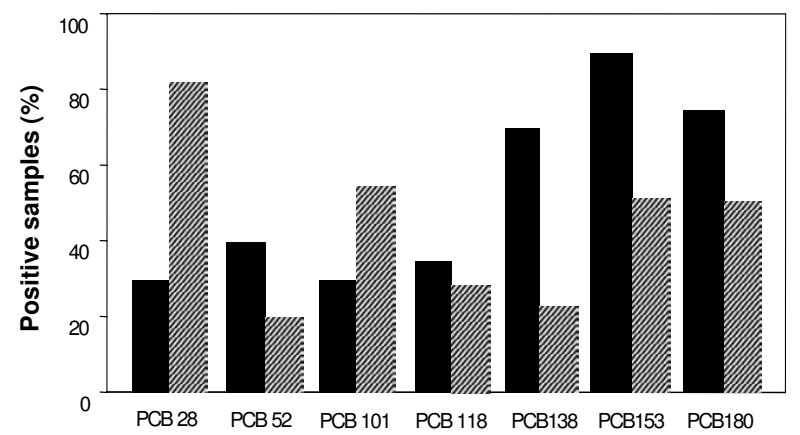

Figure 3

Distribution of individual PCB congeners in samples from the Adriatic Sea ( $\square$ ) and the Tyrrhenian ( $($ ) Sea. Species from the Adriatic Sea were more contaminated than those collected in the Tyrrhenian Sea. Number of positive samples $(n)$ for individual $P C B$ congener in the Adriatic Sea: PCB $28(n=6)$, PCB $52(n=8)$, PCB I0I $(n=6)$, PCB I I8 (n = 7), PCB I $38(n=14), P C B ~ I 53(n=18), P C B ~ I 80(n$ $=15)$. Number of positive samples $(n)$ for individual $P C B$ congener in the Tyrrhenian Sea: PCB $28(n=18)$, PCB 52 ( $=4), P C B|0|(n=\mid 2), P C B|| 8(n=7), P C B \mid 38(n=5)$, PCB I53 $(n=I I)$, PCB I80 $(n=I I)$.

presence of 17b-estradiol (positive control), solvent (negative control), pure chemicals and organic extracts. Dimethylsulphoxide (DMSO) was used as solvent. Solutions of standard PCB congeners and extracts were evaporated under a gentle flow of nitrogen and the pellet was resuspended in $10 \mu \mathrm{l}$ DMSO.

PCB standards were tested at $5 \mu \mathrm{g} / \mathrm{ml}$. Congeners 138 and 153 were assayed at $0.05 \mu \mathrm{g} / \mathrm{ml}$ because at higher concentrations strongly inhibited yeast cells growth. The samples were added to the yeast culture so that the concentration of solvent DMSO did not exceed $1 \%(\mathrm{v} / \mathrm{v})$.

\section{b-galactosidase assay}

Yeast cells were harvested by centrifugation and the pellet was resuspended in $1 \mathrm{ml}$ of Z-buffer $(60 \mathrm{mM}$ $\mathrm{Na}_{2} \mathrm{HPO}_{4} \cdot 7 \mathrm{H}_{2} \mathrm{O}, 40 \mathrm{mM} \mathrm{NaH}{ }_{2} \mathrm{HPO}_{4} \cdot \mathrm{H}_{2} \mathrm{O}, 10 \mathrm{mM} \mathrm{KCl}$, $1 \mathrm{mM} \mathrm{MgSO}_{4} \cdot 7 \mathrm{H}_{2} \mathrm{O}$, and $35 \mathrm{mM}$ 2-mercaptoethanol, $\mathrm{pH}$ 7.0). After centrifugation, the pellet was resuspended in $150 \mu \mathrm{l}$ of Z-buffer. The cells were permeabilized by adding $50 \mu \mathrm{l}$ dichloromethane, $20 \mu \mathrm{l} 0.1 \%$ SDS, 5-50 $\mu \mathrm{l}$ resuspended cells (out of $150 \mu \mathrm{l}$ ) plus Z-buffer for a total of 150 $\mu \mathrm{l}$ including cells, followed by vortexing for $10 \mathrm{~s}$. The enzymatic reaction was started by adding $700 \mu \mathrm{l} 2 \mathrm{mg} / \mathrm{ml}$ o-nitrophenyl b-D-galactopyranoside (ONPG) to the Zbuffer and incubating at $30^{\circ} \mathrm{C}$ for $5-10 \mathrm{~min}$. The reaction was terminated by the addition of $500 \mu \mathrm{l} 1 \mathrm{M} \mathrm{Na}_{2} \mathrm{CO}_{3}$ and the absorbance at $420 \mathrm{~nm}\left(\mathrm{OD}_{420}\right)$ of the sample was measured. The b-gal activity was normalised to the number of cells assayed and expressed as Miller units using the following formula [18]:

b-gal units $($ M.U. $)=\left(1000 \times \mathrm{OD}_{420}\right) /\left(\mathrm{t} \times \mathrm{V} \times \mathrm{OD}_{600}\right)$

$\mathrm{t}=$ length of incubation $(\mathrm{min}) \mathrm{V}=$ volume of culture used in the assay $(\mathrm{ml})$

The b-galactosidase activity induction elicited by estradiol, the reference estrogen, showed a sigmoid shape (Figure 1) and adequately fitted a linear dose-response relationship after Log transformation of Miller Units.

The b-galactosidase activity of the samples was expressed as a percentage of the activity obtained with $10 \mathrm{nM}$ E2 (positive control) [19].

\section{Statistical analysis}

Chemo-analytical and biological results were processed using Principal Components Analysis (PCA) [20,21] and Partial Least Square regression (PLS) [22]. Principal Components Analysis is a rotation of the original data in order to orientate the first new axis in the direction of the maximum explained variance. The second new axis will be oriented perpendicularly to the first, in order to maximise the residual variance, and so on until all the information of the system is explained. Using Principal Components Analysis is possible to:

a) estimate correlation between variables

b) display objects (finding outliers, clusters, ...)

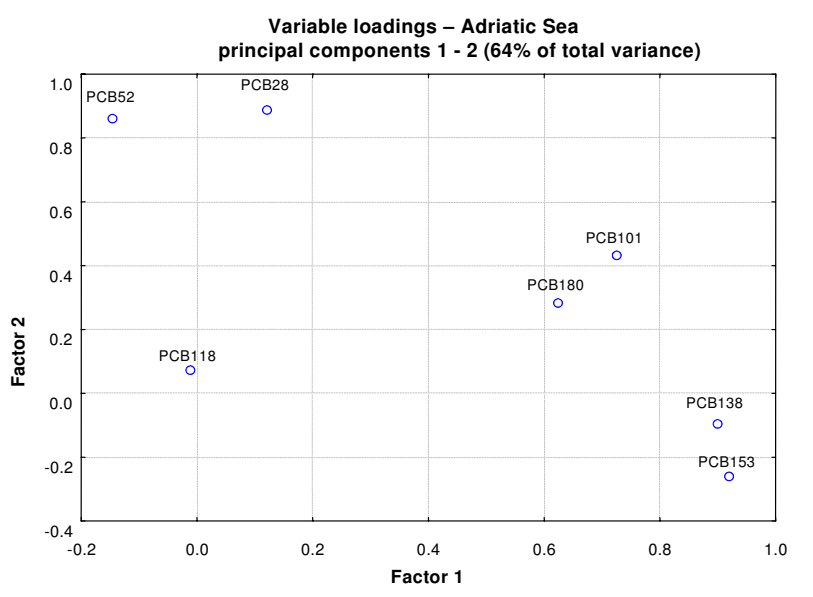

Figure 4

Principal components analysis loading plot of PCBs contamination in samples collected in the Adriatic Sea. 
Table I: PCB concentrations (ng/g wet weight) determined in marine species collected in Adriatic and Tyrrhenian Sea

\begin{tabular}{|c|c|c|c|c|c|c|c|c|c|}
\hline Adriatic Sea samples & Fat (g\%) & PCB 28 & PCB 52 & PCB IOI & PCB II 8 & PCB I38 & PCB I53 & PCB I 80 & PCB \\
\hline I. H. dactilopterus & 0.3 & $N^{a}$ & ND & ND & ND & 73 & 8 & n.d & 81 \\
\hline 2. I. coindetii & 0.5 & ND & ND & ND & ND & 37 & 42 & 109 & 188 \\
\hline 3. I. coindetii & 0.5 & ND & ND & ND & ND & 26 & 41 & 72 & 139 \\
\hline 4. M. barbatus & 1.7 & ND & ND & ND & 76 & 184 & 264 & 208 & 732 \\
\hline 5. M. barbatus & 1.4 & ND & ND & 15 & ND & 123 & 168 & 137 & 443 \\
\hline 6. M. merluccius & 0.4 & 46 & 4 & 7 & 10 & 21 & 27 & 11 & 126 \\
\hline 7. M. merluccius & 0.8 & 41 & 4 & 10 & 12 & 37 & 48 & 52 & 204 \\
\hline 8. M. merluccius & 0.9 & 44 & 5 & 18 & 23 & 69 & 82 & 29 & 270 \\
\hline 9. M. merluccius & 0.4 & ND & 39 & 14 & ND & 56 & 66 & 21 & 196 \\
\hline 10. M. merluccius & 0.4 & ND & ND & ND & ND & ND & 9 & ND & 9 \\
\hline II. P. phycis & 0.6 & 15 & ND & ND & 55 & ND & ND & ND & 70 \\
\hline 12. P. phycis & 0.6 & ND & ND & ND & ND & 6 & 7 & 12 & 25 \\
\hline 13. P. phycis & 0.8 & ND & I & ND & 10 & ND & 6 & ND & 17 \\
\hline 14. P. phycis & 0.5 & ND & I & ND & 8 & ND & 5 & ND & 14 \\
\hline 15. P. phycis & 0.7 & ND & ND & ND & ND & 6 & 8 & 12 & 26 \\
\hline 16. P. longirostris & 0.4 & ND & 2 & ND & ND & 2 & 4 & 8 & 16 \\
\hline 17. S. scombrus & 0.5 & 244 & ND & 135 & ND & 497 & 196 & 92 & 1164 \\
\hline 18. S. scombrus & 0.6 & ND & ND & ND & ND & ND & 78 & 400 & 478 \\
\hline 19. S. scombrus & 0.6 & 1469 & 191 & ND & ND & ND & ND & 125 & 1785 \\
\hline 20. S. scombrus & 0.7 & ND & ND & ND & ND & 320 & 311 & 6 & 637 \\
\hline Tyrrhenian Sea samples & Fat (g\%) & РСB 28 & РCB 52 & PCB IOI & РСB II8 & РCB I38 & PCB I53 & PCB 180 & PCB \\
\hline I. L. vulgaris & 0.7 & 12 & $\mathrm{ND}^{a}$ & ND & ND & ND & ND & ND & 12 \\
\hline 2. L. vulgaris & 0.6 & 18 & ND & ND & ND & 1 & ND & ND & 19 \\
\hline 3. M. barbatus & 1.3 & 5 & ND & ND & 1 & ND & 5 & 2 & 13 \\
\hline 4. M. barbatus & 1.2 & ND & ND & ND & ND & ND & 1 & 1 & 2 \\
\hline 5. M. barbatus & 1.4 & 10 & ND & 15 & ND & ND & ND & 1 & 26 \\
\hline 6. M. cephalus & 0.6 & 7 & 1 & 1 & ND & ND & ND & ND & 9 \\
\hline 7. P. phycis & 0.5 & 6 & ND & 1 & 3 & ND & 6 & 2 & 18 \\
\hline 8. P. phycis & 0.7 & 17 & 6 & ND & ND & ND & 2 & ND & 25 \\
\hline 9. P. phycis & 1.5 & ND & ND & 1 & ND & ND & 2 & 4 & 7 \\
\hline 10. P. phycis & 0.8 & 3 & ND & ND & ND & ND & 3 & ND & 6 \\
\hline II. M. poutassou & 0.4 & ND & ND & 13 & 9 & 1 & 2 & 1 & 26 \\
\hline 12. M. poutassou & 0.4 & 8 & 3 & 27 & 25 & 15 & ND & ND & 78 \\
\hline 13. O. vulgaris & 0.6 & 2 & ND & 1 & ND & ND & ND & ND & 3 \\
\hline 14. O. vulgaris & 0.7 & 5 & ND & ND & ND & ND & ND & ND & 5 \\
\hline 15. O. vulgaris & 0.6 & 17 & ND & 2 & 3 & ND & 1 & 1 & 24 \\
\hline 16. O. vulgaris & 0.5 & 5 & ND & ND & ND & ND & ND & ND & 5 \\
\hline I7. S. aurata & 1.2 & 1 & 2 & 11 & 16 & ND & ND & ND & 30 \\
\hline 18. S. officinalis & 0.6 & ND & ND & ND & ND & ND & ND & 3 & 3 \\
\hline 19. S. officinalis & 0.6 & 4 & ND & ND & ND & ND & 3 & 2 & 9 \\
\hline 20. S. scombrus & 0.4 & 4 & ND & 3 & ND & 3 & ND & ND & 10 \\
\hline 2I. S. scombrus & 0.3 & 7 & ND & 3 & 10 & ND & 3 & 2 & 25 \\
\hline 22. S. scombrus & 0.8 & 5 & ND & 16 & ND & 4 & 6 & 3 & 34 \\
\hline
\end{tabular}

aND detection limit
c) summarise the "information" of a system
d) reduce dataset dimension
e) find mean aspect of the system

PLS regression is a biased regression method that allow to obtain very stable models and it can be used also when the ratio cases/predictors is smaller then one and when there are predictors that are strongly correlated.

This method uses predictors PCs and responses to find the couple that as got the best correlation and goes on using 
Table 2: b-galactosidase activity induced by PCB congeners (standard solutions)

\begin{tabular}{lcc}
\hline Congeners & Concentrations $\mu \mathbf{g} / \mathbf{m l}^{\mathbf{a}}$ & b-galactosidase activity (percent of 10 nM E2) \\
\hline PCB 28 & 5.0 & $31.10 \pm 6.58$ \\
PCB 52 & 5.0 & $31.96 \pm 7.82$ \\
PCB I0 & 5.0 & $18.35 \pm 4.26$ \\
PCB I 18 & 5.0 & $85.88 \pm 19.79$ \\
PCB I38 & 0.05 & $20.95 \pm 7.82$ \\
PCB I53 & 0.05 & $26.37 \pm 5.63$ \\
PCB I80 & 5.0 & $22.92 \pm 8.67$
\end{tabular}

${ }^{a}$ Congeners 138 and 153 were assayed at $0.05 \mu \mathrm{g} / \mathrm{ml}$ because at higher concentrations they strongly inhibited yeast cells growth

other PCs until there is still usable "information". At the end the number of PLS components to be used is the one that let maximise the explained variance in prediction.

Expected estrogenicity according to the content of individual PCBs measured in each sample was calculated from the chemical data for each sample by using the principle of concentration additivity and relative potencies of the various chemicals as determined with the yeast estrogen screen.

The use of Log transformation of PCB and b-galactosidase activity values normalised their distribution and stabilised the variance allowing the use of parametric methods. The Statgraphics Plus statistical package was used (Magnugistic, Rockville MD, USA).

\section{Results}

\section{PCBs assessment}

Twenty samples of marine organisms from the Adriatic Sea and 22 from the Tyrrhenian Sea, mainly belonging to species, M. barbatus, S. scombrus, P. phycis, M. merluccius and $O$. vulgaris were analysed for the presence of seven ref-

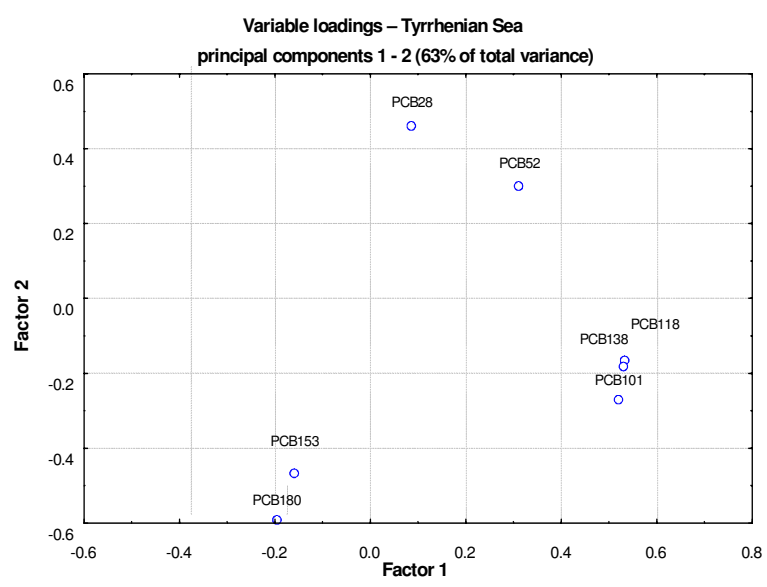

Figure 5

Principal components analysis loading plot of PCBs contamination in samples collected in the Tyrrhenian Sea. erence PCBs, namely PCB 28, PCB 52, PBC 101, PCB 118, PCB 138, PCB 153 and PCB 180. They were chosen because considered to be suitable indicators of industrial marine pollution by International Agencies. Forty-one percent of 294 chemical determinations gave negative results (under the detection limit). Total PCB concentrations ranged from 0.002 up to $1.785 \mathrm{ng} / \mathrm{g}$ wet weight. Species from the Adriatic Sea were more contaminated than those collected in the Tyrrhenian Sea (Table 1) and the analysis of variance showed that this difference was statistically significant ( $p=0.002$ ) (Figure 2).

Individual PCB congeners distribution also differed depending on the area of fishing (Figure 3). The species collected in the Adriatic Sea were more often contaminated with hexa- and heptachlorobiphenyls, and this is in accord to studies from other authors [23], whereas samples collected in the Tyrrhenian Sea were mostly contaminated by PCB 28.

Multivariate statistical analysis (PCA) showed different groups of correlation between the PCBs in the two datasets. The first two principal components are able to explain $64 \%$ of variance in the Adriatic dataset, and $63 \%$ of variance in the Thyrrenian dataset (Figures 4, 5).

Taking into account the species, the multifactor analysis of variance showed that the difference in PCBs contamination observed in the two seas is mainly due to the PCBs content of $S$. scombrus and $M$. barbatus. These species showed for samples collected in the Adriatic Sea, higher concentrations of total PCBs (Table 1), accordingly to other authors [24].

\section{b-galactosidase activity}

The b-galactosidase activity elicited by seafood extracts is reported in Figure 6 and Figure 7. Thirty-eight percent of seafood samples showed ER-mediated responses higher than $10 \%$ E2. The greatest response measured was $42.96 \%$ of the activity elicited by the natural hormone. Tyrrhenian samples were more frequently positive than Adriatic ones (50\% versus $25 \%$ ), although the analysis of variance did not denote any significant differences between the agonis- 
Table 3: Comparison of the estrogenic activity in the same species from the two habitats

\begin{tabular}{|c|c|c|c|c|c|}
\hline \multirow[t]{2}{*}{ Species } & \multicolumn{2}{|c|}{ Adriatic Sea } & \multicolumn{2}{|c|}{ Tyrrhenian Sea } & \multirow[b]{2}{*}{ Fisher's exact test } \\
\hline & Number of samples & $\begin{array}{c}\text { Number of positive } \\
\text { samples }\end{array}$ & Number of samples & $\begin{array}{c}\text { Number of positive } \\
\text { samples }\end{array}$ & \\
\hline M. barbatus & 2 & - & 3 & 2 & $p>0.3$ \\
\hline P. phycis & 5 & - & 4 & 2 & $p>0.16$ \\
\hline S. scombrus & 4 & - & 3 & 2 & $p>0.14$ \\
\hline Total & 11 & 0 & 10 & 6 & $p<0.004$ \\
\hline
\end{tabular}

tic activity $(p=0.13)$. S. scombrus, O. vulgaris, $P$. phycis, $M$. barbatus were the more frequently inducing species in Tyrrhenian samples, while for the Adriatic samples the estrogen-like activity was mainly due to $M$. merluccius.

\section{PCBs and b-galactosidase activity correlation}

The content of total PCBs and b-galactosidase activity did not show any significant correlation (a negative borderline correlation was observed, $p=0.07$ ).

The PLS analysis showed that in samples with estrogenic activity higher than $10 \% \mathrm{E} 2$, the most observed combination of these contaminants was PCB 28, PCB 101, PCB 153, PCB 180.

However, total PCBs concentration explained only 33\% and $15.77 \%$ of variance, respectively in samples from the Tyrrhenian and the Adriatic Sea.

To better investigate these results, the $\beta$-galactosidase activity of individual PCBs was assessed in the yeast assay. The results are showed in Table 2 . The b-galactosidase activity of PCB standards ranged from $18.35 \%$ (PCB 101) up to $85.88 \%$ (PCB 118), with PCB 118 resulting the

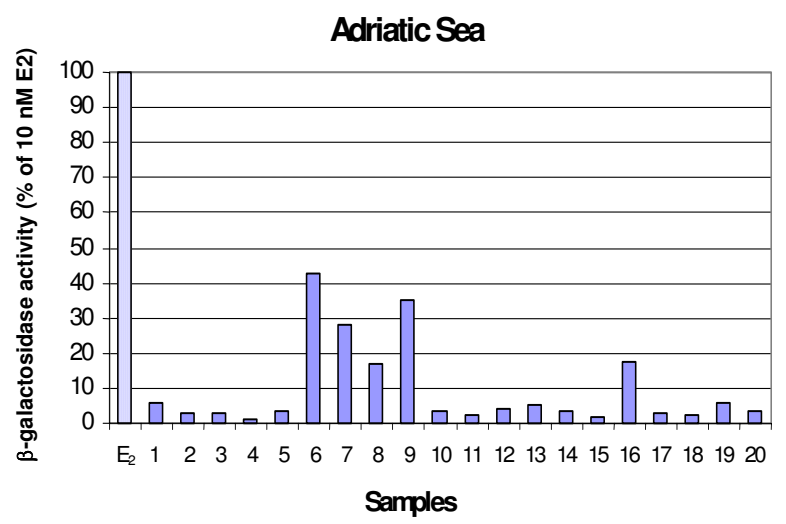

Figure 6

b-galactosidase activity induced by tissue extracts of seafood from the Adriatic Sea. Results are expressed as percent activity induced by $10 \mathrm{nM}$ E2. most estrogenic in the yeast assay. This congener belongs to the class of 12 PCBs identified by the WHO as "dioxinlike" because of their toxicity and certain features of their structure which make them similar to 2, 3, 7, 8-tetrachlorodibenzo-p-dioxin $(2,3,7,8$-TCDD).

The predicted response according to the individual content of PCBs measured in each seafood sample was calculated. Comparison between predicted and measured enzymatic activity showed a statistically significant difference depending on the two areas. In the Tyrrhenian Sea enzymatic activity measured in the samples was higher than the expected activity, while an inverse correlation was found in the Adriatic Sea. The biological effects of polychlorinated biphenyls (PCBs) are often similar to (although less potent than) those of TCDD by activating the aryl hydrocarbon (Ah) receptor. Additionally, some PCBs or mixtures of PCBs exhibit agonistic activity, whereas others are actually antiestrogenic $[2,25,26]$. Thus, the estrogenic activity of each congener was determined but the prediction of the effect of the same congener in vivo may be extremely difficult, depending on the interactions in a complex environmental mixture.

In this study we analysed the content of PCBs because of their well-documented ability to influence the endocrine system. However, fish tissue may contain a mixture of several environmental compounds other than PCBs interfering with the endocrine system due to the widespread contamination of surface waters with scarcely treated urban and industrial waste that could have additive, synergistic or antagonistic effects. This may account for the final biological activity observed in the samples. Actually, the United States Environmental Protection Agency (USEPA) estimates there are more than 87,000 of potential EDCs.

Nevertheless, detecting so many chemicals would take an unreasonable investment of time and resources, so it is necessary to develop screening programs using short term bioassays to assess the risk of exposure for biota to endocrine disrupting chemicals through the environment and diet. 


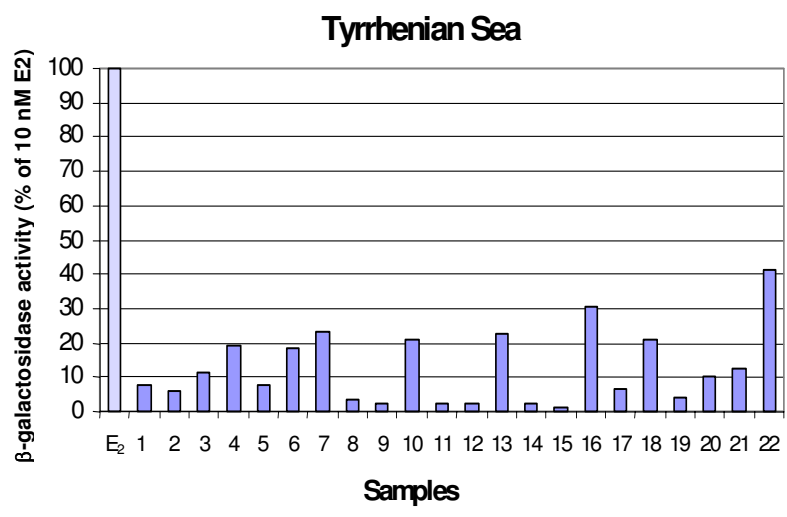

Figure 7

b-galactosidase activity induced by tissue extracts of seafood from the Tyrrhenian Sea. Results are expressed as percent activity induced by $10 \mathrm{nM}$ E2.

Finally, we underline that endogenous hormones could interfere in the estrogen-like activity elicited by animal organic extracts, marine organisms included as recently pointed out by some authors [27]. It is known that in marine organisms, estrogen level may vary depending on differences in species, sex, age, life cycle and season and we tested a raw fat extract in which endogenous hormones are still present. Thirteen species with different habitat and reproductive periods were analysed, and for three species (M. barbatus, P. phycis, S. scombrus) collected both in the Adriatic Sea and in the Tyrrhenian Sea in the same sampling season, statistically significant differences (Fisher's exact test: $\mathrm{p}<0.004$ ) in $\beta$-galactosidase activity were observed when considered on the whole (Table 3 ). This result may indicate the role of the aquatic environment in bioaccumulation of xenoestrogens.

\section{Conclusion}

Most studies have been focused on the evaluation of the content of environmental contaminants such as PCBs and related persistent organic pollutants (POPs) into tissues of fish and other aquatic organisms $[5,7,23,28-30]$ or on reproductive effects due to in vivo exposure in natural environment $[31,32]$ or to specific sources of pollution [33-35].

In our monitoring we detected a generally low PCBs content in most seafood samples and alone they can not justify the estrogenicity of the extracts. The approach proposed in this work, namely to measure the overall estrogenicity of chemicals each presented at low concentrations, may suggest the probable intake of estrogen-like chemicals for humans.
Then, a useful application of the yeast assay could be aimed to direct chemical analyses to only biologically active samples as a first monitoring level. This bioassay may provide a useful integration to chemical approach, and could be used to identify edible seafood exposed to estrogenic organic chemicals, depending on geographical natural habitat. As yet, however, there is a paucity of analytical data on extracts of edible marine organisms exhibiting estrogenic activity. Fish products may represent an important dietary source of environmental contaminants with endocrine activity to humans, particularly when they represent a relevant part of food intake [11,36]. Many compounds may be present in the environment in trace amounts, but have high biological activity. It is important to assess health risk for biota and the level exposure to environmental contaminants. The foetus and the newborns in humans are particularly vulnerable to pollutants exposure due to transplacental and lactational transfer of maternal burdens at critical periods of development [37]. The scientific evidence demonstrated a link between chronic exposure to low concentrations of chemicals through the environment or the food-chain and reproductive animal health $[31,34,38]$. Subtle health effects have been documented in certain Arctic populations exposed to a variety of contaminants present in the food chain (in traditional foods), particularly mercury and PCBs and the greatest concern is for fetal and neonatal development $[37,39,40]$. The possibility that bio-accumulative properties of persistent organic chemicals with hormone-like activity and the chronic low level exposure may contribute to overall breast cancer risk in women, as well as reproductive and developmental effects in humans [10,41] has heavy implications for the prevention of these diseases in western countries.

\section{Abbreviations}

EDCs: endocrine disrupting chemicals

PCBs: polychlorinated biphenyls

WHO: World Health Organization

ICES: International Council for the Exploration of the Seas

US-EPA: United States Environmental Protection Agency

E2: $17 \beta$-estradiol

DMSO: dimethylsulfoxide

PCA: principal component analysis

PLS: partial least square regression 
GC-MS: gas chromatography-mass spectrometry

GC-EDC: gas chromatography coupled with electron capture detector

\section{Competing interests}

The author(s) declare that they have no competing interests.

\section{Authors' contributions}

SG and BP carried out the biological analyses and helped to draft the manuscript, TC collected the samples and performed the chemical analyses, MC provided statistical data analysis, RAC participated in the conceiving of the study, DR participated in the design of the study and in coordination and led the writing of the manuscript. All authors read and approved the final manuscript.

\section{Acknowledgements}

This research was partially supported by the Italian Ministry of the Environment.

\section{References}

I. Garner CE, Jefferson WN, Burka LT, Matthews HB, Newbold RR: In vitro estrogenicity of the catechol metabolites of selected polychlorinated biphenyls. Toxicol Appl Pharmacol 1999, I54: 188-197.

2. Moore M, Mustain M, Daniel K, Chen I, Safe S, Zacharewski T, Gillesby B, Joyeux A, Balaguer P: Antiestrogenic activity of hydroxylated polychlorinated biphenyl congeners identified in human serum. Toxicol Appl Pharmacol 1997, I42:160-168.

3. Salama J, Chakraborty $\mathrm{TR}, \mathrm{Ng}$ L, Gore AC: Effects of polychlorinated biphenyls on estrogen receptor-beta expression in the anteroventral periventricular nucleus. Environ Health Perspect 2003, I I I: I278-1282

4. United States Environmental Protection Agency, Office of Water. Update: National Listing of Fish and Wildlife Advisories. EPA-823F-03-003 2003.

5. Fernandez MA, Gomara B, Bordajandi LR, Herrero L, Abad E, Abalos $M$, Rivera J, Gonzalez MJ: Dietary intakes of polychlorinated dibenzo-p-dioxins, dibenzofurans and dioxin-like polychlorinated biphenyls in Spain. Food Addit Contam 2004, 2 1:983-991.

6. Smith AG, Gangolli SD: Organochlorine chemicals in seafood: occurrence and health concerns. Food Chem Toxicol 2002 40:767-779.

7. Antunes $P$, Gil O: PCB and DDT contamination in cultivated and wild Sea bass from Ria de Aveiro, Portugal. Chemosphere 2004, 54: I503-I507.

8. Svensson BG, Hallberg T, Schultz A, Hagmar L: Parameters of immunological competence in subjects with high consumption of fish contaminated with persistent organochlorine compounds. Arch Occup Environ Health 1994, 65:35|-358.

9. Faroon O, Keith MS, Jones D, de Rosa C: Effects of polychlorinated biphenyls on development and reproduction. Toxicol Ind Health 2001, 1 7:63-93.

10. Brouwer A, Longnecker MP, Birnbaum LS, Cogliano J, Kostyniak P, Moore J, Schantz S, Winneke G: Characterization of potential endocrine-related health effects at low dose levels of exposure to PCBs. Environ Health Perspect I999, I 07(Suppl 4):639-649.

II. Judd N, Griffith WC, Faustman EM: Contribution of PCB exposure from fish consumption to total dioxin-like dietary exposure. Regul Toxicol Pharmacol 2004, 40: I25-I35.

12. Schantz SL, Gasior DM, Polverejan E, McCaffrey RJ, Sweeney AM, Humphrey HE, Gardiner JC: Impairments of memory and learning in older adults exposed to polychlorinated biphenyls via consumption of Great Lakes fish. Environ Health Perspect 200I, |09:605-6II.
13. Istituto Superiore di Sanità. Istisan Report 02/38 ISSN / / 23-3 / / 7, ISS, Roma 2002

14. Liu JW, Picard D: Bioactive steroids as contaminants of the common carbon source galactose. FEMS Microbiol Lett 1998 I59:167-|7|.

15. Liu JW, Jeannin E, Picard D: The anti-estrogen hydroxytamoxifen is a potent antagonist in a novel yeast system. Biol Chem 1999, 380:1341-1345.

16. Pinto $B$, Picard D, Reali D: A recombinant yeast strain as a short term bioassay to assess estrogen-like activity of xenobiotics. Ann Ig 2004, I 6:579-585.

17. Pinto B, Garritano S, Reali D: Occurrence of estrogen-like substances in the marine environment of the Northern Mediterranean Sea. Mar Poll Bull 2005, 50: I68I-I685.

18. Miller JH: Experiments in Molecular Genetics New York: Cold Spring Harbour Laboratory Press; 1972.

19. Gong Y, Chin HS, Lim LS, Loy CJ, Obbard JP, Yong EL: Clustering of sex hormone disruptors in Singapore's marine environment. Environ Health Perspect 2003, I I I:|448-|453.

20. Jackson JE: $A$ user's guide to principal components New York, NY: John Wiley \& Sons, Inc; 1991.

21. Jolliffe IT: Principal Components Analysis New York Inc., NY: SpringerVerlag; 1986.

22. Martens H, Næs T: Multivariate Calibration Chichester, UK: John Wiley \& Sons; 1989.

23. Storelli MM, Giacominelli-Stuffler R, D'Addabbo $R$, Marcotrigiano GO: Health risk of coplanar polychlorinated biphenyl congeners in edible fish from the Mediterranean Sea. J Food Prot 2003, 66:2176-2179

24. Perugini $M$, Cavaliere $M$, Giammarino $A$, Mazzone $P$, Olivieri $V$, Amorena $M$ : Levels of polychlorinated biphenyls and organochlorine pesticides in some edible marine organisms from the Central Adriatic Sea. Chemosphere 2004, 57:391-400.

25. Layton AC, Sanseverino J, Gregory BW, Easter JP, Sayler GS, Schultz TW: In vitro estrogen receptor binding of PCBs: measured activity and detection of hydroxylated metabolites in a recombinant yeast assay. Toxicol Appl Pharmacol 2002 180:157-163.

26. Bonefeld-Jørgensen EC, Andersen HR, Rasmussen TH, Vinggaard AM: Effect of highly bioaccumulated polychlorinated biphenyl congeners on estrogen and androgen receptor activity. Toxicology 200I, I 58:14|-I53.

27. Rivas A, Fernandez MF, Cerrillo I, Ibarluzea I, Olea-Serrano MF Pedraza $V$, Olea N: Human exposure to endocrine disrupters: standardisation of a marker of estrogenic exposure in adipose tissue. APMIS 200I, I09:185-197.

28. Miao X-S, Swenson C, Woodward LA, Li QX: Distribution of polychlorinated biphenyls in marine species from French Frigate Shoals, North Pacific Ocean. Sci Tot Environ 2000, 257:17-28.

29. Bayarri S, Baldassarri LT, lacovella N, Ferrara F, di Domenico A PCDDs, PCDFs, PCBs and DDE in edible marine species from the Adriatic Sea. Chemosphere 200I, 43:60I-6I0.

30. Llobet JM, Bocio A, Domingo JL, Teixido A, Casas C, Muller L: Levels of polychlorinated biphenyls in food from Catalonia, Spain: estimated dietary intake. J Food Prot 2003, 66:479-484.

31. Oberdörster E, Cheek AO: Gender benders at the beach: endocrine disruption in marine and estuarine organisms. Environ Toxicol Chem 2000, 20:23-36.

32. De Metrio G, Corriero A, Desantis S, Zubani D, Cirillo F, Deflorio M, Bridges CR, Eicker J, de la Serna JM, Megalofonou P, Kime DE: Evidence of a high percentage of intersex in the Mediterranean swordfish (Xiphias gladius L.). Mar Poll Bull 2003, 46:358-36I.

33. Jobling S, Casey D, Rogers-Gray T, Oehlmann J, Schulte-Oehlmann U, Pawlowski S, Baunbeck T, Turner AP, Tyler CR: Comparative responses of molluscs and fish to environmental estrogens and an estrogenic effluent. Aquat Toxicol 2004, 66:207-222.

34. Nash JP, Kime DE, Van der Ven LT, wester PW, Brion F, Maack G Stahlschmidt-Allner $P$, Tyler CR: Long-term exposure to environmental concentrations of the pharmaceutical ethynylestradiol causes reproductive failure in fish. Environ Health Perspect 2004, I I 2: I 725-I733.

35. Tyler CR, Spary C, Gibson R, Santos EM, Shears J, Hill EM: Accounting for differences in estrogenic responses in rainbow trout (Oncorhynchus mykiss: salmonidae) and roach (Rutilus rutilus: Cyprinidae) exposed to effluents from wastewater treatment works. Environ Sci Technol 2005, 39:2599-2607. 
36. Grimvall E, Rylander L, Nilsson-Ehle P, Nilsson U, Strömberg U, Hagmar L, Östman C: Monitoring of polychlorinated biphenyls in human blood plasma: methodological developments and influence of age, lactation, and fish consumption. Arch Environ Contam Toxicol 1997, 32:329-336.

37. Grandjean P, Weihe P, Burse VW, Needham LL, Storr-Hansen E, Heinzow B, Debes F, Murata K, Simonsen H, Ellefsen P, Budtz-Jorgensen E, Keiding N, White RF: Neurobehavioural deficits associated with PCB in 7-year-old children prenatally exposed to seafood neurotoxicants. Neurotoxicol Teratol 200I, 23:305-3I7.

38. Fossi MC, Casini S, Marsili L, Neri G, Mori G, Ancora S, Moscatelli A, Ausili A, Notarbartolo-di-Sciara G: Biomarkers for endocrine disruptors in three species of Mediterranean large pelagic fish. Marine Environ Res 2002, 54:667-67I.

39. Dewailly $E$, Weihe $P$ : The effect of Arctic pollution on population health. AMAP 2003. AMAP Assessment 2002: Human health in the Arctic, Chapter 9 2003:xiv+ 37 [http://www.amap.no]. Arctic Monitoring and Assessment Programme (AMAP), Oslo, Norway HH_CO9.pdf ISBN 82-797I-0 16-7

40. Bonefeld-Jørgensen EC, Ayotte P: Toxicological properties of persistent organic pollutants and related health effects of concern for the Arctic populations. AMAP 2003. AMAP Assessment 2002: Human health in the Arctic, Chapter 6 2003:xiv+ I 37 [http:/ /www.amap.no]. Arctic Monitoring and Assessment Programme (AMAP), Oslo, Norway HH_CO6.pdf ISBN 82-797I-016-7

41. Dallinga JW, Moonen EJ, Dumoulin JC, Evers JL, Geraedts JP, Kleinjans JC: Decreased human semen quality and organochlorine compounds in blood. Hum Reprod 2002, 17:1973-1979.

\section{Publish with Biomed Central and every scientist can read your work free of charge}

"BioMed Central will be the most significant development for disseminating the results of biomedical research in our lifetime. "

Sir Paul Nurse, Cancer Research UK

Your research papers will be:

- available free of charge to the entire biomedical community

- peer reviewed and published immediately upon acceptance

- cited in PubMed and archived on PubMed Central

- yours - you keep the copyright

Submit your manuscript here:

http://www.biomedcentral.com/info/publishing_adv.asp
BioMedcentral 